\title{
SEROPREVALENCE OF BOVINE VIRAL DIARRHEA ON SMALLHOLDER FARMS ON THE TERRITORY OF BELGRADE CITY
}

\author{
Zorana ZUROVAC SAPUNDŽIĆ*, Milan NINKOVIĆ, Dimitrije GLIŠIĆ, \\ Bojan MILOVANOVIĆ, Jadranka ŽUTIĆ, Branislav KURELJUŠIĆ, \\ Vesna MILIĆEVIĆ
}

Institute of Veterinary Medicine of Serbia, Belgrade, Serbia

(Received 06 April, Accepted 27 July 2021)

\begin{abstract}
Bovine viral diarrhea (BVD) is a viral disease of cattle with a high economic impact. To estimate the seroprevalence of Bovine viral diarrhea virus (BVDV) infection of cattle on smallholder farms we included 78 smallholder farms in the Belgrade epizootiological area where 318 blood serum samples from cattle were collected, and subsequently tested. The samples were analyzed using a commercially available competitive enzyme immunoassay (ELISA) for the detection of antibodies against BVDV. The obtained results showed an overall seroprevalence of $3.8 \%$ whereas the seroprevalence on herd level varied from $0 \%$ to $80 \%$. The obtained results showed a relatively low seroprevalence of BVD infection on smallholder farms on the territory of Belgrade city.
\end{abstract}

Keywords: Belgrade, Bovine viral diarrhea, BVDV, cattle, ELISA, seroprevalence

\section{INTRODUCTION}

Bovine viral diarrhea (BVD) is a highly contagious viral disease of cattle with a high economic impact due to decreased performance and milk production, reproductive disorders and increased mortality. Based on the International Committee on Taxonomy of Viruses (ICTV), Bovine viral diarrhea virus (BVDV) is classified as a member of the family Flaviviridae, genus Pestivirus [1]. According to the new clasification BVDV is divided into Pestivirus A (previously named genotype 1) and Pestivirus B (previously named genotype 2). BVDV causes digestive, reproductive, and respiratory disorders that range from mild to severe ones [2]. Although BVDV primarily affects cattle, some other species like small ruminants and pigs can be infected, as well. The disease is also present in wildlife affecting wild boars and other wild ruminants [3]. The infection is endemic worldwide and produces significant financial losses [4]. Presently, some EU countries are free or almost free from BVD [5], while others, before launching eradication programs, had reported relatively high BVD seroprevalance, in Croatia

\footnotetext{
*Corresponding author: e-mail: zorana991@hotmail.com
} 
at 7.,9\% [6] and Hungary at $43.4 \%$ [7]. Losses from BVD associated with other diseases can be more than $€ 340$ per cow in a herd outbreak [4]. Though indirect losses are substantial, the greatest economic losses due to BVDV infection are a direct consequence of the virus passing through the placenta of infected, gestating cows, making reproductive losses due to abortion, early embryonic death, malformations of the fetus, and reduced conception rate [8].

There are numerous ways of introducing BVDV into a herd, such as acquisition of animals and movement of animals between the herds, via semen, embryos, and vaccines (live and attenuated) [2]. Persistently infected cattle are the major reservoir of the virus thus providing the continuous circulation of the virus in the herd [8].

BVD can be diagnosed through direct virus detection or indirectly by detection of antibodies. The most used methods are ELISAs, RT-PCR assays, immunohistochemistry (IHC), and virus isolation [9]. The most often used serological method for laboratory diagnostics of BVD through detection of specific antibodies is blocking ELISA [10]. Serological methods are useful for screening of whole herds and estimation of BVD antibody levels, as well as identification of infected animals that are responsible for the spread of the disease [11]. Identification of persistently infected individuals, is an important tool to eradicate BVDV [12]. Although ELISA is the most frequently applied method, RT-PCR assay is more sensitive and specific, being also very reliable for the estimation of a herd BVD status [13].

Previously published studies, although limited and outdated, confirmed the existence of the virus on the territory of Serbia, consequently suggesting the considerable prevalence of BVD, particularly on big cattle farms [14-16]. Considering the relatively poor data available, besides the time gap and insufficient exact and updated knowledge regarding BVD seroprevalence with emphasis on smallholder farms, epizootiologically attractive due to the specific way of farming, we aimed to distinctly determine the seroprevalence of BVD on smallholders farms on the territory of Belgrade city.

\section{MATERIAL AND METHODS}

In this research, 78 smallholder farms with a total of 463 animals, both cows and heifers were included. Only adult cows, above the age of 24 months were sampled, resulting with 318 blood serum samples collected individually and subsequently tested. The enrolled animals were apparently healthy and have never been vaccinated against BVDV. The collected samples originated from animals residing on different smallholder farms within seven municipalities of the city Belgrade (Mladenovac, Lazarevac, Sopot, Barajevo, Grocka, Stepojevac, Surčin). The average herd size was 5.94 individuals (herd size varied from 1 to 17), while sample size from each sampled herd varied from 1 to 14 . Although the exact definition of smallholder farms varies widely worldwide depending on location and the farming system, regarding the law regulation of the Republic of Serbia smallholder farms are defined as holdings were 
less than 20 ruminants are raised, typically under the control of one owner [17]. Also, this indicates that the implemented biosecurity measures on smallholder farms are usually low.

Blood samples were collected during the summer 2019. by puncture of the Vena coccigea in a sterile tube containing a clot activator $(10 \mathrm{ml})$. After spontaneous coagulation and centrifugation (3000 $\mathrm{rpm}$ for 10 minutes), the serum samples were decanted and stored at the temperature of $-20{ }^{\circ} \mathrm{C}$ until the analyses were performed.

The samples were analyzed using competitive enzyme immunoassay (ELISA) for the detection of antibodies against BVDV infection (PrioCHECK ${ }^{\mathrm{TM}}$ Rum. BVD p80 Ab Serum \& Milk, Prionics, Zurich, Switzerland), according to the manufacturer's instructions. The optical density (OD) was measured with the ELISA reader (Multiscan, Labsystem) at a single wavelength of $450 \mathrm{~nm}$. Samples were considered as positive when S/P (sample to positive) ratio was above the cut-off value of 0.5 . According to the manufacturer, the diagnostic sensitivity and specificity values of the used ELISA kit for BVDV antibodies detection were $96.9 \%$ and $97.8 \%$, respectively.

The required sample size and true seroprevalence estimation due to imperfections of the test used (BlakerCL) with a confidence level of 0.95 were calculated using the Sergeant, ESG, 2018. Epitools Epidemiological Calculators. Ausvet. [18]. The required sample size for relevant BVD seroprevalence estimation concerning the 78 smallholder farms included in this study was calculated at minimum of 209 cattle, (population size 463, confidence limits 5\%, design prevalence 1.0, and clusters 1). Pearson's Chi-Squared Test together with the Fisher's Exact Test were used to estimate the significance of the divergence between the obtained results.

Results are presented as seroprevalence at herd level, the overall seroprevalence, and true seroprevalence within each mentioned municipality.

\section{RESULTS}

In total, out of 318 tested cows for the presence of antibodies against BVDV, 12 cows were found to be seropositive, indicating that the overall seroprevalence of BVD infection within the mentioned Belgrade municipalities was 3.8\%. The most BVD seropositive cows were located in the municipality Surčin (7 cows), following Barajevo (3 cows) and Sopot (2 cows), while the highest seroprevalence at herd level was observed precisely in the municipality Surčin (80\%).

The true seroprevalence of BVDV on smallholder farms within the implied Belgrade municipalities ranges from $0 \%$ to $76.9 \%$.

Pearson's Chi-Squared Test has shown a statistically significant divergence between the results obtained from municipalities Barajevo, Surčin and Sopot $(\mathrm{P}<0.05)$. Furthermore, when comparing the results obtained from the mentioned municipalities with each other mutually, using Fisher's Exact Test the divergence between the obtained 
results from Barajevo versus Surčin, and Surčin versus Sopot has shown to be statistically significant $(\mathrm{P}<0.05)$. Nevertheless, the divergence between the results obtained from Barajevo versus Sopot was not statistically significant $(\mathrm{P}>0.05)$.

Data of the seroprevalence study of BVDV on the observed farms on the territory of Belgrade city are presented in Table 1 .

Table 1. Seroprevalence of Bovine viral diarrhea on smallholders' farms on the territory of Belgrade

\begin{tabular}{|c|c|c|c|c|c|c|}
\hline \multirow{2}{*}{$\begin{array}{l}\text { Municipality } \\
\text { of Belgrade }\end{array}$} & \multirow{2}{*}{$\begin{array}{c}\text { No of } \\
\text { smallholders' } \\
\text { farms }\end{array}$} & \multirow{2}{*}{$\begin{array}{l}\text { No } \\
\text { analyzed } \\
\text { animals }\end{array}$} & \multirow{2}{*}{$\begin{array}{l}\text { No of } \\
\text { positive } \\
\text { animals }\end{array}$} & \multicolumn{3}{|c|}{ Results of the seroprevalence study } \\
\hline & & & & $\begin{array}{c}\text { Seroprevalence } \\
\text { at herd level }\end{array}$ & $\begin{array}{c}\text { The overall } \\
\text { seroprevalence }\end{array}$ & $\begin{array}{c}\text { True } \\
\text { seroprevalence }\end{array}$ \\
\hline Mladenovac & 11 & 57 & 0 & 0 & 0 & 0 \\
\hline Lazarevac & 10 & 26 & 0 & 0 & 0 & 0 \\
\hline Sopot & 11 & 63 & 2 & $18.2 \%(2 / 11)$ & $3.2 \%(2 / 63)$ & $0-32.9 \%$ \\
\hline Barajevo & 33 & 125 & 3 & $9.1 \%(3 / 33)$ & $2.4 \%(3 / 125)$ & $0-32.9 \%$ \\
\hline Grocka & 4 & 23 & 0 & 0 & 0 & 0 \\
\hline Stepojevac & 4 & 8 & 0 & 0 & 0 & 0 \\
\hline Surčin & 5 & 16 & 7 & $80 \%(4 / 5)$ & $43.7 \%(7 / 16)$ & $0-76.9 \%$ \\
\hline Total: & 78 & 318 & 12 & $11.5 \%(9 / 78)$ & $3.8 \%(12 / 318)$ & $1.7 \%$ \\
\hline
\end{tabular}

\section{DISCUSSION}

With its worldwide high negative economic impact on agriculture and animal welfare, BVD represents an important disease which should be monitored and controlled very thoughtfully. On the territory of our country, the first serologically confirmed cases of BVDV infection were published in 1968 [19]. Since then, not many authors have dealt with this disease, hence data regarding the seroprevalence of BVD on the territory of Serbia are insufficient and outdated, and seek further surveys.

According to official data of the Statistical Office of the Republic of Serbia total number of cattle population in 2019. in Serbia was 898.178, of those 45.721 (5.1\%) were kept in the region of city Belgrade at the time of sampling [20].

The situation in the dairy sector in our country has changed over the past decades. With a herd less than 20 cows, smallholder farms used to be considered as the biggest producers of milk in Serbia [21]. Along with the development of agriculture, a new trend is noticed, where the dominance in the dairy sector is increasingly taken over by large farming systems. As previously mentioned, opposite to large farming systems, implemented biosecurity measures on smallholders farms are commonly low.

As there is neither a BVDV control program in Serbia nor a mandatory vaccination program, the observed results reflect the natural course of the infection in the ruminant population in our country. Previously published studies have shown that 
the seroprevalence of BVD on large cattle farms was in a wide range from $3.80 \%$ to $81.58 \%$ [16]. Petrović (2006) has published the results of an extensive research where within animals farmed on smallholder farms, the obtained seroprevalence ranged from $18.53 \%$ to $31.30 \%$, depending on the epizootiological area. Contrary to this, regarding cattle farmed on large farms, this value was from $55.13 \%$ to $81.58 \%$. The highest seroprevalence of BVD was obtained precisely in the Belgrade epizootiological area [16] . Contrary to this, in the present study the overall seroprevalence of BVD on the territory of Belgrade on smallholder farms was 3.8\%. This result is in accordance with data published by Milošević et al. (2004), where the seroprevalence of BVD among animals in small herds on the territory of the Belgrade district was $4.24 \%$ [15]. The seroprevalence of BVD in the neighboring countries varies. A study that covered several European countries between 1974-1995 revealed that the overall seroprevalence of BVD varied between 60 and 85\% [22]. Since then the situation has certainly changed, but the course of the change dependends on a number of factors. A meta-analysis of BVDV prevalence in the global cattle population that covered 73 different countries for the period 1961-2016 revealed that seroprevalence of BVD remained relatively constant at both animal $(48.73 \%-46.26 \%)$ and herd level $(67.01 \%-66.08 \%)$ [23]. A decrease of BVD seroprevalence was predicted for Europe, while an increase in North America [23]. In the surrounding countries, Hungary has reported an overall seroprevalence of BVD $43.4 \%$ with $70.4 \%$ seropositive farms [7]. Our results revealed far lower $(11.5 \%$ BVD seropositive farms) on the territory of Belgrade city. The difference between the results obtained from municipalities Barajevo, Surčin and Sopot, considered as statistically significant, may come from the divergence concerning the density of the sampled population.

As presented, there is an obvious difference between the seroprevalence of BVDV infection on large cattle farms compared to smallholder cattle farms. The difference in the seroprevalence of BVDV infection between large farms and smallholder farms could be explained by the limited animal movements since females usually stay within the herd with a rare introduction of new animals. Human traffic on smallholder farms is lower than on large farms, and the animals are tended only by the people living on the farm thus reducing the chance for the introduction of BVDV into the herd by workers. In addition, livestock feed is mostly homemade, excluding the need for procurement of industrial feed that could be potentially the source of the virus. Persistently infected animals (virus-positive, but antibody-negative animals) are a major source of the virus within the herd, continuously shedding enormous amounts of the virus via all body secretions and hence sustain the mechanism for maintaining BVDV in the cattle population [24].

Another concern in light of spreading BVDV is cattle kept on pastures which easily become a reservoir of the virus for the wildlife, thus feedback is established and the possibility for the re-infection of cattle remains open. As BVDV is confirmed in wild boars in Serbia, these species along with other wild ruminants represent the constant risk and could jeopardize BVDV eradication programs in domestic cattle [3]. 
Furthermore, BVD is a transient and self-limiting infection, the virus spreads laterally but in the lack of a naïve population, the possibility of further dissemination is highly reduced [25].

Attempts to eradicate BVDV were limited for a long time due to prophylactic vaccination, however, nowadays there are strategies that have shown to be very successful and are underway in several European countries. Scandinavian countries have been one of the first that have applied BVDV eradication programs and could serve as a model that could be applied in our country, as well. On the example of the lumpy skin disease outbreak in 2016., where due to mass vaccination the epizootic in Serbia was successfully stopped in a short term, there are reasonable bases that provide arguments for the effectual implementation of BVDV eradication programs involving vaccination [26]. Biosecurity measures together with their strict implementation would be extremely helpful besides for the request for BVDV-free animals that are introduced into the herds.

In summary, BVD is considered sporadic in Serbia on smallholder farms in the region of the city Belgrade. Our study has shown that the overall seroprevalence of BVD infection on the territory of Belgrade is $3.8 \%$. The seroprevalence of BVD at the herd level varies from $0 \%$ to $80 \%$. Consequently, while choosing an appropriate BVD control program and/or vaccination protocols all relevant data and existing conditions should be taken into concern. So far no BVD eradication programs are ongoing in Serbia, nevertheless, this remains to be implemented in the future.

\section{Acknowledgements}

The study was funded by the Serbian Ministry of Education, Science and Technological Development (Contract No 451- 03- 9/2021- 14/200030).

\section{Authors' contributions}

$\mathrm{VM}$ and JŽ conceived of the study, participated in its design and coordinated the work. BK organised sampling and collecting data together with BM and MN. ZZS, MN, DG and BM carried out the immunoassays and drafted the manuscript. ZZS and DG performed statistical analysis. All authors read and approved the final manuscript.

\section{Declaration of conflicting interests}

The author(s) declared no potential conflicts of interest with respect to the research, authorship, and/or publication of this article. 


\section{REFERENCES}

1. Smith DB, Meyers G, Bukh J, Gould EA, Monath T, Muerhoff AS, Pletnev A, Rico-Hesse R, Stapleton JT, Simmonds P, Becher: Proposed revision to the taxonomy of the genus Pestivirus, family Flaviviridae. J Gen Virol. 2017;

2. Lindberg ALE, Alenius S: Principles for eradication of bovine viral diarrhoea virus (BVDV) infections in cattle populations. Vet Microbiol. 1999;64:197-222.

3. Milićević V, Maksimović-Zorić J, Veljović L, Kureljušić B, Savić B, Cvetojević Đ, Jezdimirović N, Radosavljević V: Bovine viral diarrhea virus infection in wild boar. Res Vet Sci 2018;119:76-78.

4. Houe H: Economic impact of BVDV infection in dairies. Biologicals 2003;31:137-43.

5. Sandvik T: Progress of control and prevention programs for bovine viral diarrhea virus in Europe. Vet Clin North Am - Food Anim Pract 2004;20:151-69.

6. Biuk-Rudan N, Cvetnić S, Madić J, Rudan D: Prevalence of antibodies to IBR and BVD viruses in dairy cows with reproductive disorders. Theriogenology 1999;51:875-81.

7. Kovágó C, Forgách P, Szabára Á, Mándoki M, Hornyák Á, Duignan C, Pásztiné Gere E, Rusvai M: Seroprevalence of bovine viral diarrhoea virus in Hungary - Situation before launching an eradication campaign. Acta Vet Hung 2015;63:255-63.

8. Baker JC: The clinical manifestations of bovine viral diarrhea infection. Vet Clin North Am Food Anim Pract 1995;11(3):425-445.

9. Sandvik T: Selection and use of laboratory diagnostic assays in BVD control programmes. Prev Vet Med 2005;72:3-16.

10. Beaudeau F, Belloc C, Seegers H, Assié S, Sellal E, Joly A: Evaluation of a blocking ELISA for the detection of bovine viral diarrhoea virus (BVDV) antibodies in serum and milk. Vet Microbiol 2001;80:329-337.

11. Humphry RW, Reeves A, Gunn GJ: Strategies for screening young stock for antibodies optimising numbers to test, cut-points, \& predictive values for bovine viral diarrhoea virus. Sci Rep 2018;8(1):9532.

12. Fray MD, Paton DJ, Alenius S: The effects of bovine viral diarrhoea virus on cattle reproduction in relation to disease control. Anim Reprod Sci 2000;60-61:615-27.

13. Bedeković T, Jemeršić L, Lojkić I, Lemo N, Keros T, Balatinac J, Brnić D, Catela Ivković T, Madić J: Bovine viral diarrhoea: Ag ELISA and reverse transcription polymerase chain reaction as diagnostic tools in pooled serum samples from persistently infected cattle Short communication. Vet Arch 2012;82:295-301.

14. Petrović T, Duričić B, Toplak I, Lazić S, Barlić Maganja D, Hostnik P, Grom J, Sandvik T: Isolation and confirmation of bovine viral diarrhoea virus in Serbia and comparative typing with recent Slovenian isolates. Acta Vet Brno 2004;54:33-42.

15. Kurćubić VS, Petrović TR, Đoković RD, Ilić Z, Mašković PZ: Rasprostranjenost BVD infekcije kod preživara u Srbiji. J Cent Eur Agric. J Cen Europ Agricult 2015;16:130-47.

16. Kurčubić V, Ilić Z, Đoković R, Jevtić S PT: Utvrđivanje prisustva i statusa infekcije uzrokovane virusom goveđe dijareje u zapatima goveda u Centralnoj Srbiji - mogućnosti za kontrolu. Veterinarski glasnik 2010;64:3-19.

17. "Sl. glasnik RS" br. $81 / 2006$. Pravilnik o veterinarsko-sanitarnim uslovima objekata za uzgoj i držanje kopitara, papkara, živine i kunića [Internet]. 2006. Available from: https:// 
zivinarstvo.com/wp-content/uploads/2014/03/pravilnik-o-veterinarsko-sanitarnimuslovima-objekata-za-uzgoj-i-drzanje-kopitara-papkara-zivine-i-kunica.pdf

18. Sergeant E. No Title. Ep. Epidemiol. Calc. Ausvet. (https//epitools.ausvet.com.au/). 2018.

19. Cvetnić S: Virusne bolesti životinja, JAZU, Stvarnost, Zagreb. 1986.

20. Republički zavod za statistiku. Broj stoke - stanje 1. decembra 2019. godine [Internet]. 2020. Available from: https://publikacije.stat.gov.rs/G2020/Pdf/G20201029.pdf

21. Goss S, Howells J, Luijkx M, Hopić S, Popović R, Jovanović Z: Dairy sector study for IPARD programme Republic of Serbia. Cardno Agrisystems Consortium, Oxfordshire, UK. 2010.

22. Houe H: Epidemiological features and economical importance of bovine virus diarrhoea virus (BVDV) infections. Vet Microbiol 1999;64:89-107.

23. Scharnböck B, Roch FF, Richter V, Funke C, Firth CL, Obritzhauser W, Baumgartner W, Käsbohrer A, Pinior B: A meta-analysis of bovine viral diarrhoea virus (BVDV) prevalences in the global cattle population. Sci Rep 2018;8:1-15.

24. Zimmer GM, Van Maanen C, De Goey I, Brinkhof J, Wentink GH: The effect of maternal antibodies on the detection of bovine virus diarrhoea virus in peripheral blood samples. Vet Microbiol 2004;100:145-9.

25. Hoar BR: Bovine Virus Diarrhea (BVD) [Internet]. UC Davis Sierra Foothill Res. Ext. Cent. 2004. Available from: https://escholarship.org/uc/item/524867fv

26. Vasković N, Debeljak Z, Vidanović D, Šekler M, Matović K, Aničić M, Marinković D: Morphological characteristics of skin lesions in cattle naturally infected with Lumpy Skin Disease Virus in Serbia. Acta Vet-Beograd.2019;69(4):369-378.

\title{
SEROPREVALENCIJA VIRUSNE DIJAREJE GOVEDA NA MALIM GAZDINSTVIMA NA TERITORIJI GRADA BEOGRADA
}

\author{
Zorana ZUROVAC SAPUNDŽIĆ, Milan NINKOVIĆ, Dimitrije GLIŠIĆ, \\ Bojan MILOVANOVIĆ, Jadranka ŽUTIĆ, Branislav KURELJUŠIĆ, \\ Vesna MILIĆEVIĆ
}

Virusna dijareja goveda (BVD) je virusno oboljenje, značajnog ekonomskog uticaja. Radi procene seroprevalencije virusne dijareje goveda na malim gazdinstvima, u istraživanje je uključeno 78 malih gazdinstava na beogradskom epizootiološkom područiju gde je 318 uzoraka krvnih seruma goveda sakupljeno i docnije ispitano. Uzorci su ispitani korišćenjem kompetitivnog enzimskog imunoeseja za detekciju antitela protiv virusa BVD (komercijalno dostupan ELISA kit). Utvrđena seroprevalencija BVD na malim vlasničkim gazdinstvima iznosi 3,8 \%, odnosno kreće se od 0 do $80 \%$ na nivou stada. Dobijeni rezultati su pokazali relativno nisku seroprevalenciju BVD infekcije na malim gazdinstvima na teritoriji grada Beograda. 